Check for updates

Cite this: RSC Adv., 2017, 7, 34160

Received 17th May 2017

Accepted 2nd July 2017

DOI: $10.1039 / c 7 r a 05579 j$

rsc.li/rsc-advances

\section{New cyclometalated Ir(III) complexes with NCN pincer and meso-phenylcyanamide BODIPY ligands as efficient photodynamic therapy agents $\uparrow$}

\begin{abstract}
Leila Tabrizi (D) *ab and Hossein Chiniforoshan*b
A new class of cyclometalated iridium(III) with NCN pincer and meso-phenylcyanamide BODIPY ligands of the formula [Ir(L)(PPY)(Pcyd-BODIPY)], 1, [Ir(L)(PIQ)(Pcyd-BODIPY)], 2, in which HL: 5-methoxy-1,3-bis (1methyl-1H-benzo[d]imidazol-2-yl)benzene, Pcyd-BODIPY: 8-(4-phenylcyanamide) BODIPY, PPY: 2phenylpyridine, PIQ: 1-phenylisoquinoline have been synthesized and studied for photodynamic therapy (PDT). The photophysical properties, DNA binding, DNA photocleavage, cellular uptake, thioredoxin reductase activity, reactive oxygen species (ROS) generation, and cellular apoptosis of the complexes have also been studied. Therefore, we present a conceivable biologically applicable PDT modality that develops persuasively designed photoactivatable Ir(III) complexes.
\end{abstract}

\section{Introduction}

Photodynamic therapy (PDT) has been successfully used for cancer treatment and involves the interaction of the photosensitizer, light, and molecular oxygen. ${ }^{1-5}$ Recently, a rutheniumbased photosensitizer (TLD-1433) has been approved for phase Ib clinical trials in Canada for non-muscle invasive bladder cancer. ${ }^{6-8}$

Some cyclometalated $\mathrm{Ru}(\mathrm{II}), \mathrm{Ir}(\mathrm{III})$, and Pt(II) complexes, $\mathrm{Ru}$ (II) arene complexes, and $\operatorname{Re}(\mathrm{I})$ tricarbonyl complexes have proven themselves for photocytotoxicity studies. ${ }^{9-15}$ Cyclometalated Ir ${ }^{\text {III }}$ complexes have recently received great interest for PDT agents due to their exceptional properties such as simple color tuning, energy-level control, high quantum yields, large Stokes shifts, long-lived phosphorescence, and ROS generation under hypoxia conditions via electron (type I) or energy transfer (type II). ${ }^{\mathbf{1 6 - 2 7}}$

BODIPY (boron dipyrromethene) derivatives have found to be applicable as potential applications for biological labeling, cellular imaging, and fluorescence sensing, unique narrow emission with high quantum yield in biological and medical fields. Furthermore, it has been found that the heavy atom substituted BODIPY dyes containing an electron-withdrawing acetoxymethyl moiety in the meso-position could be enhanced photostability for the PDT agents. ${ }^{28-32}$ Recently, our groups focused attention in the development $\mathrm{Ni}(\mathrm{II}), \mathrm{Zn}(\mathrm{II}), \mathrm{Cd}(\mathrm{II}), \mathrm{Co}(\mathrm{II})$, Ru(II), Ir(III), Pt(II), Pd(II), and triorganotin(Iv) complexes

${ }^{a}$ School of Chemistry, National University of Ireland, Galway, University Road, Galway, Ireland. E-mail: LEILA.TABRIZI@nuigalway.ie

${ }^{b}$ Department of Chemistry, Isfahan University of Technology, Isfahan, Iran. E-mail: Chinif@cc.iut.ac.ir

$\dagger$ Electronic supplementary information (ESI) available. See DOI: 10.1039/c7ra05579j containing phenylcyanamide derivatives as monodentate ligands in regard to traditional chemotherapy and PDT applications. ${ }^{33-39}$ With the aim of enhancing the photophysical and photobiological properties of BODIPY ligands in cyclometalated Ir(III) complexes, we have designed new monodentate ligand by linking meso-BODIPY ligands to phenylcyanamide ligands.

Here we present the synthesis, characterization, photophysical properties, and photocytotoxicity explorations of two new cyclometalated $\operatorname{Ir}(\mathrm{III})$ complexes of the type $[\operatorname{Ir}(\mathrm{L})(\mathrm{PPY})(\mathrm{Pcyd}-$ BODIPY)], 1, [Ir(L)(PIQ)(Pcyd-BODIPY)], 2, in which HL: 5methoxy-1,3-bis (1-methyl-1H-benzo[d]imidazol-2-yl)benzene, Pcyd-BODIPY: 8-(4-phenylcyanamide) BODIPY, PPY: 2-phenylpyridine, PIQ: 1-phenylisoquinoline.

\section{Results and discussion}

\subsection{Synthesis and characterization}

The ligand 8-(4-phenylcyanamide) BODIPY (Pcyd-BODIPY) was synthesized from 8-(4-anilino) BODIPY as previously reported. ${ }^{40}$ The ligand HL was synthesized as previously reported by us. ${ }^{\mathbf{4 1}}$ Reaction of $\mathrm{IrCl}_{3} \cdot x \mathrm{H}_{2} \mathrm{O}$ with pincer ligand $\mathrm{HL}$ in $\mathrm{MeOH} / \mathrm{CH}_{2} \mathrm{Cl}_{2}$ $(1: 1, v / v)$ and then PPY (2-phenylpyridine) or PIQ (1-phenylisoquinoline) and Pcyd-BODIPY in $\mathrm{MeOH} / \mathrm{CH}_{2} \mathrm{Cl}_{2}(1: 2, \mathrm{v} / \mathrm{v})$ in $\mathrm{pH} \sim 7$ gave the complexes 1 and 2 (Fig. 1).

The ligand Pcyd-BODIPY and complexes were prepared in excellent yield and in high purity as described in the experimental section. Complexes were characterized by elemental analysis, IR, ${ }^{1} \mathrm{H}$ NMR, ${ }^{13} \mathrm{C}$ NMR spectroscopy (Fig. S1-S6†) and ESI-TOF mass spectrometry (Fig. S7-S9†).

The formation of Pcyd-BODIPY, 1, and $\mathbf{2}$ is clearly evidenced by the parent peaks in the mass spectra. The mass spectra of Pcyd-BODIPY, 1, and 2 show peaks of $(\mathbf{M}+\mathrm{H})^{+}$centered at $\mathrm{m} / \mathrm{z}=$ 365, 1078, and 1128, respectively (Fig. S7-S9†). 


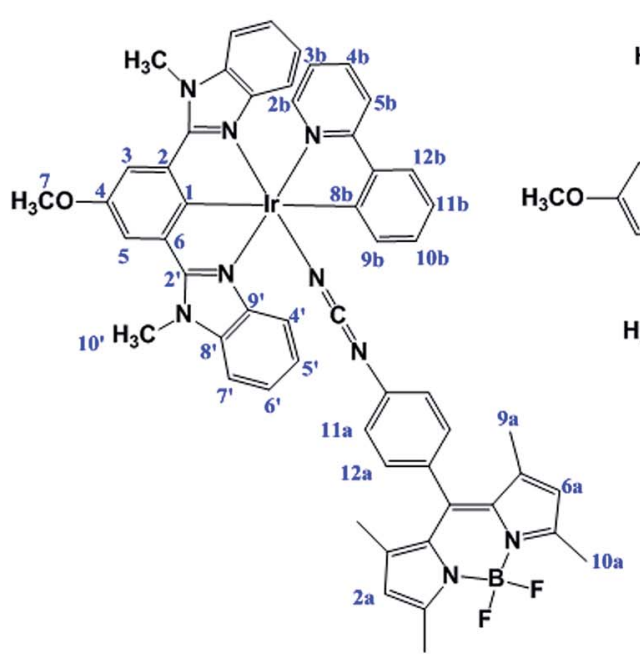

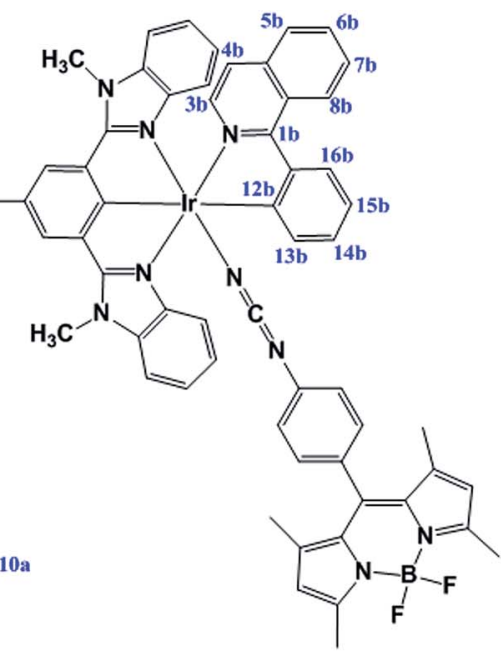

2

Fig. 1 Structure of complexes 1 and 2 .

The disappearance of the $\mathrm{H} 1$ signal (7.54 ppm in ligand $\mathrm{HL}$ ) and the upfield shift of the signal of $\mathrm{H} 3 / \mathrm{H} 5$ of the central phenyl ring (7.29-7.35 ppm in ligand HL and 6.75 and $6.79 \mathrm{ppm}$ in 1 and 2 , respectively) in the ${ }^{1} \mathrm{H}$ NMR spectra of 1 and 2 are consistent with the coordination of Ir to the deprotonated pincer ligand. The $\mathrm{H} 4^{\prime}$ resonance is shifted downfield due to the ring current effect of the second ligand in complexes $\mathbf{1}$ and 2 (7.84-7.79 ppm in ligand HL and 8.31 and $8.80 \mathrm{ppm}$ in $\mathbf{1}$ and 2, respectively). ${ }^{41}$

The proton chemical shifts of Pcyd-BODIPY decrease with respect to the free ligand due to coordination of ligand PcydBODIPY to Ir. Also, the NH proton of ligand Pcyd-BODIPY disappeared due to coordination of the cyanamide group to Ir in complexes $\mathbf{1}$ and 2.

The $\nu$ (NCN) band of ligand Pcyd-BODIPY is observed at 2225 $\mathrm{cm}^{-1}$, when the Pcyd-BODIPY ligand coordinates to Ir, $\nu$ (NCN) of complexes $\mathbf{1}$ and $\mathbf{2}$ is shifted to lower energies (2092 and 2088 $\mathrm{cm}^{-1}$, respectively) representing the coordination of cyanamide through the cyano nitrogen.

\subsection{Photophysical properties}

The photophysical properties of $\operatorname{Ir}(\mathrm{III})$ complexes in acetonitrile and phosphate buffer solution (PBS) were considered at $298 \mathrm{~K}$ (Fig. S10, S11, and Table S1 $\dagger$ ). The complexes 1 and 2 display the absorption bands of lower intensity in the $300-480 \mathrm{~nm}$ region due to intraligand (IL) $\pi \rightarrow \pi^{*}$ and $\mathrm{n} \rightarrow \pi^{*}$ transitions and singlet and triplex metal-to-ligand charge transfer $\left({ }^{1} \mathrm{MLCT}\right.$ and $\left.{ }^{3} \mathrm{MLCT}\right){ }^{42}$ In addition, the absorption spectra of complexes $\mathbf{1}$ and $\mathbf{2}$ are dominated by the intense bands at 541 and $526 \mathrm{~nm}$ in acetonitrile, respectively, due to the $S_{0} \rightarrow S_{1}\left(\pi-\pi^{*}\right)$ transition localized on the BODIPY unit. ${ }^{43}$ The complexes 1 and 2 exhibited red emissions in acetonitrile and PBS upon excitation at $500 \mathrm{~nm}$.

The luminescence quantum yields $\left(\Phi_{\mathrm{em}}\right)$ and luminescence lifetimes were evaluated in acetonitrile at room temperature
(Table S1†). The luminescence lifetimes of complexes $\mathbf{1}$ and $\mathbf{2}$ are around $700 \mathrm{~ns}$. These complexes have higher quantum yields and longer lifetimes than $\left[\mathrm{Ru}(\mathrm{bpy})_{3}\right]^{2+}$ and $\mathrm{Ru}(\mathrm{II})$ pincer complexes. ${ }^{37,42}$

\subsection{Singlet oxygen sensitization}

The major cytotoxic species in PDT is the singlet oxygen to induce cancer cell death. ${ }^{44}$ Therefore, the determination of ${ }^{1} \mathrm{O}_{2}$ quantum yields of complexes $\mathbf{1}$ and 2 was made upon irradiation at $500 \mathrm{~nm}$ (Table $\mathrm{S} 2 \uparrow$ ). The ${ }^{1} \mathrm{O}_{2}$ photosensitizing properties of 1 and 2 were investigated by direct and indirect

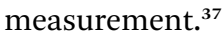

The complexes 1 and 2 have $\Phi\left({ }^{1} \mathrm{O}_{2}\right)$ values of $79 \%$ and $92 \%$ in acetonitrile (500 nm, direct method), respectively. The obtained values for $\mathbf{1}$ and $\mathbf{2}$ in acetonitrile are comparable with ${ }^{1} \mathrm{O}_{2}$ quantum yields reported for related compounds. ${ }^{37,45-47}$ These data display that the complexes $\mathbf{1}$ and $\mathbf{2}$ have a great efficacy in the photosensitization of molecular oxygen. Moreover, the quantum yields of ${ }^{1} \mathrm{O}_{2}$ production in PBS are low (Table S2 $\uparrow$ ). Thus, the effect of solvent on the efficiency of ${ }^{1} \mathrm{O}_{2}$ production is obvious. In acetonitrile, the photosensitization of molecular oxygen is effective due to the absence of quenching mechanism on the triplet excited state. ${ }^{48}$

As a result, these complexes can produce ${ }^{1} \mathrm{O}_{2}$ when they accumulate in hydrophobic compartments and complex 2 has the highest quantum yield of singlet oxygen production, emission and fluorescence lifetime.

\subsection{Interaction of 1-3 with DNA}

2.4.1. DNA binding studies. DNA is generally the primary intracellular target of anticancer drugs, so the interaction between small molecules and DNA can block the division of cancer cells and cause in cell death. ${ }^{49,50}$ The interaction of $\mathbf{1}$ and 

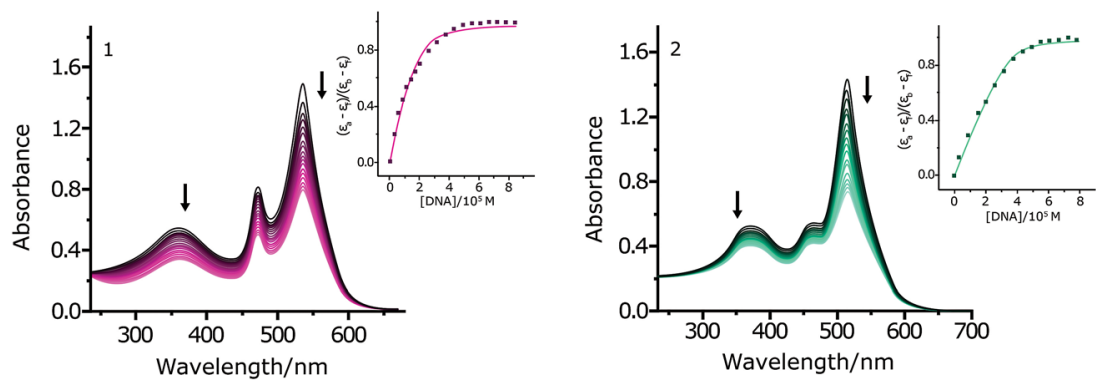

Fig. 2 Absorption spectra of complexes 1 and 2 in Tris-HCl, pH 7.2, buffer upon addition of CT DNA. [Complex] $=5.0 \mu M$, [DNA] $=0-100 \mu M$. The arrows show the direction of increasing DNA concentration.

2 with CT DNA was studied by UV-vis absorption and fluorescence spectroscopy.

Electronic absorption spectroscopy is an efficient method to study the binding mode of metal complexes to DNA. The binding ability of complexes 1 and 2 with CT DNA was considered by considering their effects on UV absorption. The $K_{\mathrm{b}}$ values were measured in Tris-HCl buffer ( $\mathrm{pH}$ 7.4) by changing the concentration of DNA from 0 to $100 \mu \mathrm{M}$ while keeping the complex concentration constant $(5 \mu \mathrm{M})$. The absorption spectra of $\mathbf{1}$ and $\mathbf{2}$ in the absence and presence of increasing amounts of CT DNA are shown in Fig. 2.

The complexes 1 and 2 exhibited hypochromicity upon adding CT DNA. Such marked changes in the intensity of spectral bands confirm an intimate association of the complex with CT DNA. The $K_{\mathrm{b}}$ values of complexes 1 and 2 are (4.39 \pm $0.2) \times 10^{5} \mathrm{M}^{-1}$ and $1.31 \times 10^{6} \mathrm{M}^{-1}$, respectively (Fig. 2, inset). Moreover, the $s$ values of complexes 1 and 2 are $(0.51 \pm 0.03)$ and $(0.91 \pm 0.03)$, respectively. A low value of $s(<1)$ could be due to an aggregation of hydrophobic molecules on the DNA surface by $\pi$ stacking. ${ }^{.1}$

This result suggests that the two complexes maybe bind to DNA by partial intercalation, involving a strong stacking interaction between the aromatic chromophore and the base pairs of the DNA. In addition, complex 2 binds with DNA more strongly than the complex 1 due to the stronger electrostatic interaction between DNA and complex 2.

The binding of the complexes 1 and 2 to CT DNA was further considered by a competitive binding fluorescence assay using ethidium bromide (EB). The EB-DNA system usually displays a major increase in the fluorescence emission when EB binds to DNA, and a decrease is observed when EB is displaced by another DNA intercalate molecule..$^{52,53}$

Fig. 3 shows the fluorescence spectra of the EB-DNA system on addition of increasing amounts of complexes 1 and 2. The intensity of the emission band at $601 \mathrm{~nm}$ of the EB-DNA system decreases by increasing concentrations of $\mathbf{1}$ and 2 .

The $K_{\mathrm{sv}}$ values that were obtained from the experiments are $(1.02 \pm 0.01) \times 10^{5} \mathrm{M}^{-1}$ and $(2.23 \pm 0.03) \times 10^{5} \mathrm{M}^{-1}$ for complexes 1 and 2 , respectively (Fig. 3, inset). $K_{\text {app }}$ was found to be $(1.15 \pm 0.02) \times 10^{5} \mathrm{M}^{-1}$ and $(2.62 \pm 0.02) \times 10^{5} \mathrm{M}^{-1}$ for complexes 1 and 2 , respectively.

These results show the same magnitude of the intrinsic binding constants determined from the absorption spectra titration, further demonstrating the absorption spectral observations that the complex 2 with the ligand PIQ can intercalate to DNA more strongly than the complex 1.

2.4.2. DNA photocleavage studies. The DNA photocleavage activity of $\mathbf{1}$ and $\mathbf{2}$ was considered using SC pUC19 DNA in Tris$\mathrm{HCl} / \mathrm{NaCl}$ buffer by irradiating the samples with visible light of $500 \mathrm{~nm}$. The complexes remain cleavage inactive in dark condition thereby prohibit possibility of any hydrolytic cleavage. All the complexes display photoinduced DNA cleavage activity in micromolar complex concentration. The complexes 1 display $73 \%$ and complex 2 show $84 \%$ cleavage of SC DNA to its nicked circular (NC) form on photoirradiation at $500 \mathrm{~nm}$ with a complex concentration of $100 \mu \mathrm{M}$ for $1 \mathrm{~h}$ (Fig. 4).
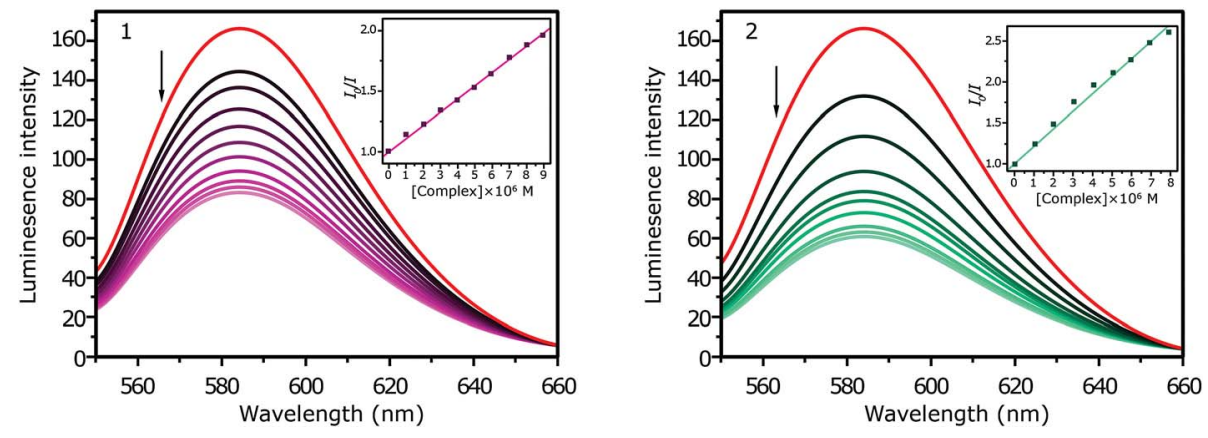

Fig. 3 Fluorescence quenching curves of EtBr bound to DNA: 1 and 2. [DNA] $=10 \mu \mathrm{M},[\mathrm{EB}]=10 \mu \mathrm{M}$, [complex] $=0-100 \mu \mathrm{M}$ (inset: plot of $I_{0} / /$ vs. [Q]). 


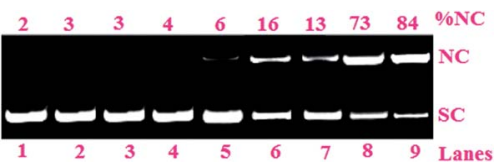

Fig. 4 Cleavage of SC pUC19 DNA $(0.2 \mu \mathrm{g}, 30 \mu \mathrm{M})$ by the complexes 1 and $2(100 \mu \mathrm{M})$ in $50 \mathrm{mM}$ Tris- $\mathrm{HCl} / \mathrm{NaCl}$ buffer $(\mathrm{pH}, 7.2)$ on photoirradiation at $500 \mathrm{~nm}$ for $1 \mathrm{~h}$ : (lane 1) DNA control; (lane 2) DNA + HL; (lane 3) DNA + PPY; (lane 4) DNA + PIQ; (lane 5) DNA + Pcyd-BODIPY; (lane 6) DNA + 1 (in dark); (lane 7), DNA + 2 (in dark); (lane 8) DNA + 1; (lane 9) DNA +2.

Addition of hydroxyl radical scavengers like DMSO, KI, catalase and superoxide radical scavengers such as superoxide dismutase, SOD did not inhibit the DNA photocleavage reaction whereas singlet oxygen quenchers such as 2,2,6,6-tetramethyl-4piperidone (TEMP), 1,4-diazabicyclo-[2.2.2] octane (DABCO), and $\mathrm{NaN}_{3}$ inhibited the DNA photocleavage activity significantly (Fig. 5). These results suggested ${ }^{1} \mathrm{O}_{2}$ are likely to be the reactive species that contribute to the cleavage process.

\subsection{Biological activity}

2.5.1. Photostability and stability in human plasma. To assess the photostability, complexes $\mathbf{1}$ and $\mathbf{2}$ were exposed to continuous light irradiation $(500 \mathrm{~nm})$ and found to reveal excellent photostability (Fig. S12 $\dagger$ ). To evaluate the stability of the complexes $\mathbf{1}$ and $\mathbf{2}$ in biological media, the stability studies was performed in human plasma by HPLC. As clearly evident from the HPLC-UV traces (Fig. S13, Table S3†), 1 and 2 displayed no obvious decomposition in plasma after three days and should be stable under physiological conditions.

2.5.2. Dark cytotoxicity and phototoxicity. The dark- and photo-cytotoxicity of the complexes $\mathbf{1}$ and $\mathbf{2}$ toward cervical cancer (HeLa) and non-cancerous (MRC-5) cell lines was evaluated using the MTT (3-(4,5-dimethylthiazol-2-yl)-2,5diphenyltetrazolium bromide) assay. The untreated control cells remained unaffected upon exposure to the same irradiation procedure and the light alone was found to be nontoxic. The complexes $\mathbf{1}$ and $\mathbf{2}$ are significantly less toxic in the dark with $\mathrm{IC}_{50}$ values of $\sim 60 \mu \mathrm{M}$ (Table 1 ). Complexes 1 and 2 , however, were significantly photocytotoxic in HeLa cells when irradiated with visible light of $500 \mathrm{~nm}$ giving $\mathrm{IC}_{50}$ values of 0.78 $\pm 0.1 \mu \mathrm{M}$ and $0.53 \pm 0.1 \mu \mathrm{M}$, respectively. Upon light irradiation, complex 2 with the ligand PIQ showed a higher cytotoxic activity in HeLa cells than $\mathbf{1}$. These $\mathrm{IC}_{50}$ values of complexes $\mathbf{1}$

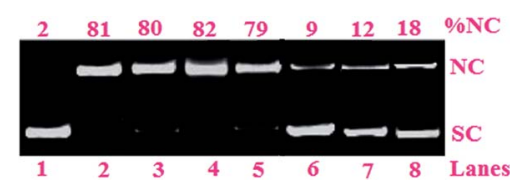

Fig. 5 Photo-induced DNA cleavage activity of complex $2(100 \mu \mathrm{M})$ in the presence of different additives at $500 \mathrm{~nm}$ for an exposure time of $1 \mathrm{~h}$ : (lane 1) DNA control; (lane 2) DNA + DMSO (2 $\mu \mathrm{L})+2$; (lane 3) DNA + KI $(0.2 \mathrm{mM})+2$; (lane 4) DNA + catalase (4 U) + 2; (lane 5) DNA + SOD $(4 \mathrm{U})+2$; (lane 6) DNA + TEMP $(0.2 \mathrm{mM})+2$; (lane 7) DNA + $\mathrm{DABCO}(0.2 \mathrm{mM})+2$; (lane 8) DNA + $\mathrm{NaN}_{3}(0.2 \mathrm{mM})+2$.
Table $1 \quad I_{50}$ values for all the complexes incubated with MRC-5 and HeLa cells in the dark and upon light irradiation

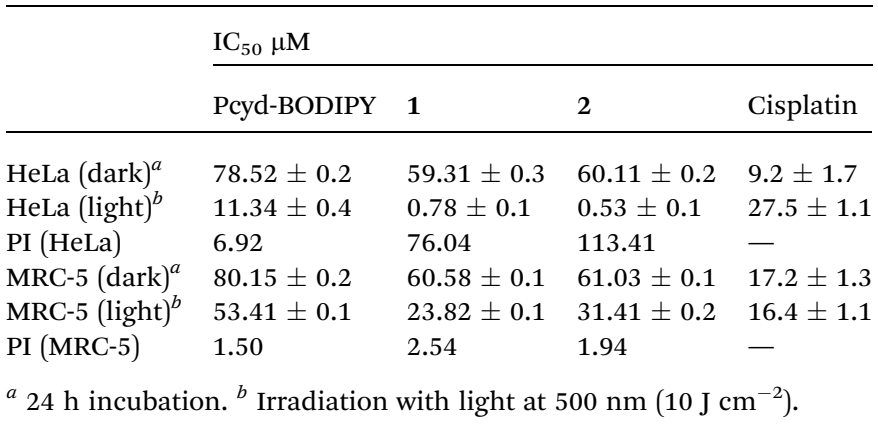

and 2 are well comparable with the activity of photofrin $\left(\mathrm{IC}_{50}\right.$ in HeLa cells $=4.3 \pm 0.2 \mu \mathrm{M}$ (visible light) and $>41 \mu \mathrm{M}$ (dark)), which is approved PDT agent. ${ }^{54}$

The phototoxicity index $\left(\mathrm{PI}=\mathrm{IC}_{50}\left(\right.\right.$ dark) $/ \mathrm{IC}_{50}$ (light)) values of complexes 1 and 2 in HeLa cells are 76.04 and 113.41, respectively. These values are auspicious considering that the commonly used photosensitizer available on the market (photofrin) with PI $>10 .^{55}$

The phototoxicity of complexes $\mathbf{1}$ and $\mathbf{2}$ on the MRC-5 cell line was also considered (Table 1), which followed the same trend observed for HeLa cells. Notably, 1 and 2 are only moderately photocytotoxic against the nontumorigenic MRC-5 cell line $\left(\mathrm{IC}_{50}=23.82\right.$ and $\left.31.41 \mu \mathrm{M}\right)$.

The ligand Pcyd-BODIPY is less toxic in the dark with $\mathrm{IC}_{50}$ values of $\sim 78 \mu \mathrm{M}$, but was significantly photocytotoxic in HeLa cells when irradiated with visible light of $500 \mathrm{~nm}$ giving $\mathrm{IC}_{50}$ value of $11.34 \pm 0.4 \mu \mathrm{M}$ (Table 1). Also, Pcyd-BODIPY is moderately photocytotoxic against the nontumorigenic MRC-5 cell line with $\mathrm{IC}_{50}=53.41 \mu \mathrm{M}$.

These complexes are comparable with cyclometalated Ir(III) complexes of styryl-BODIPY ligands with $\mathrm{IC}_{50}$ values $2.58-6.18$ $\mu \mathrm{M}$ and 8.16-9.81 $\mu \mathrm{M}$ on photoirradiation and in the dark for LLC cells (lung cancer cells) cell lines, respectively. ${ }^{56}$

2.5.3. Cellular uptake. The amounts of iridium associated with HeLa cells incubated with the complexes 1 and 2 were determined using ICP-MS. An average cell contained 7.28 \pm 0.2 and $13.06 \pm 0.1 \mathrm{fmol}$ of iridium for complexes 1 and 2 , respectively, which is comparable to those reported in the cellular uptake studies of other iridium complexes. ${ }^{57,58}$ The complex 1 exhibited lower cellular uptake efficiency than the complex 2 . The cellular uptake efficiency of complexes $\mathbf{1}$ and $\mathbf{2}$ is closely related to their cytotoxicity that is in accordance with other reported studies. ${ }^{57,58}$

2.5.4. ROS generation and cellular apoptosis. To evaluate the potential of complexes $\mathbf{1}$ and $\mathbf{2}$ to generate intracellular reactive oxygen species (ROS), HeLa cells were treated with of complexes 1 and 2 for $12 \mathrm{~h}$ and stained with $2^{\prime}, 7^{\prime}$-dichlorofluorescein diacetate (DCFH-DA) (Fig. 6). DCFH-DA can be oxidized by cellular ROS to produce 2,7-dichlorofluorescein (DCF), thereby providing an emission band centered at $525 \mathrm{~nm}$ $\left(\lambda_{\text {ex }}=490 \mathrm{~nm}\right) .{ }^{27}$ To determine the formation of ROS inside the cells, HeLa cells were incubated with complexes 1 and 2 for $4 \mathrm{~h}$ in the dark, and then were exposed to light irradiation $(500 \mathrm{~nm})$ 

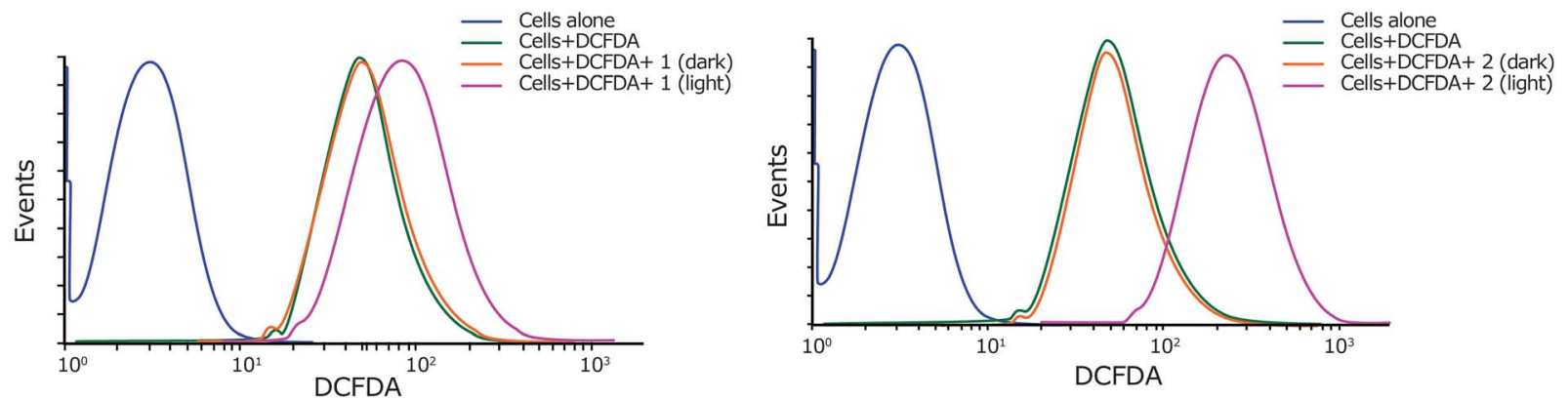

Fig. 6 Cellular ROS generation by complexes 1 and 2 in HeLa cells in dark or light conditions as estimated by DCFDA assay (pre-incubation: $4 \mathrm{~h}$ in dark, light exposure: $500 \mathrm{~nm}, 1 \mathrm{~h}$ ).

for $1 \mathrm{~h}$. The results exhibit that the complexes generate ROS in HeLa cells only upon photo-irradiation but not in the dark (Fig. 6). A good shift in the fluorescence bands was observed for the cells treated with the photo-irradiated complex 2 as compared to complex 1 that could be related to the higher cellular uptake of complex 2 than 1 (Fig. 6 and 7).

To evaluate the number of cells undergoing apoptosis, the Annexin-V-FITC/PI assay was performed by complexes $\mathbf{1}$ and $\mathbf{2}$ in HeLa cells. Cells were incubated with the complexes for $4 \mathrm{~h}$ in dark followed by light irradiation $(500 \mathrm{~nm})$. Complex 2 induced features of early apoptosis in $\sim 86 \%$ of the cells upon light (500 $\mathrm{nm}$ ) exposure in comparison with $\sim 64 \%$ for complex 1 under identical experimental conditions. The observed early apoptotic cell population in the dark was $16.46 \%$ and $16.17 \%$ for $\mathbf{1}$ and 2 , respectively, demonstrating the importance of light exposure to observe apoptotic cell death (Fig. 8).

2.5.5. TrxR inhibition. As thioredoxin reductase is significant in the intracellular redox metabolism and also plays important roles as target for new anticancer compounds, TrxR inhibition of complexes $\mathbf{1}$ and 2 were evaluated at increasing concentrations, and the dose-effect curves are displayed in Fig. 9. Furthermore, the TrxR-inhibitory activities of the complexes were also compared with auranofin, a gold phosphine complex widely used as positive TrxR inhibitor. ${ }^{59}$ As presented in Fig. 9, under the same concentrations, the

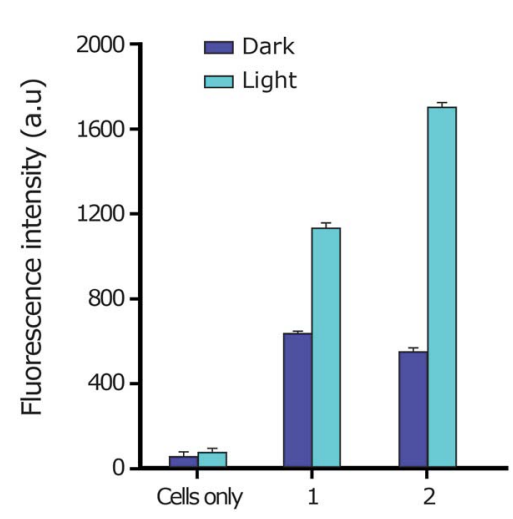

Fig. 7 DCFH-DA assay showing generation of ROS in HeLa cells treated with complexes 1 and 2 for $4 \mathrm{~h}$ in the dark and exposed to light (500 nm).
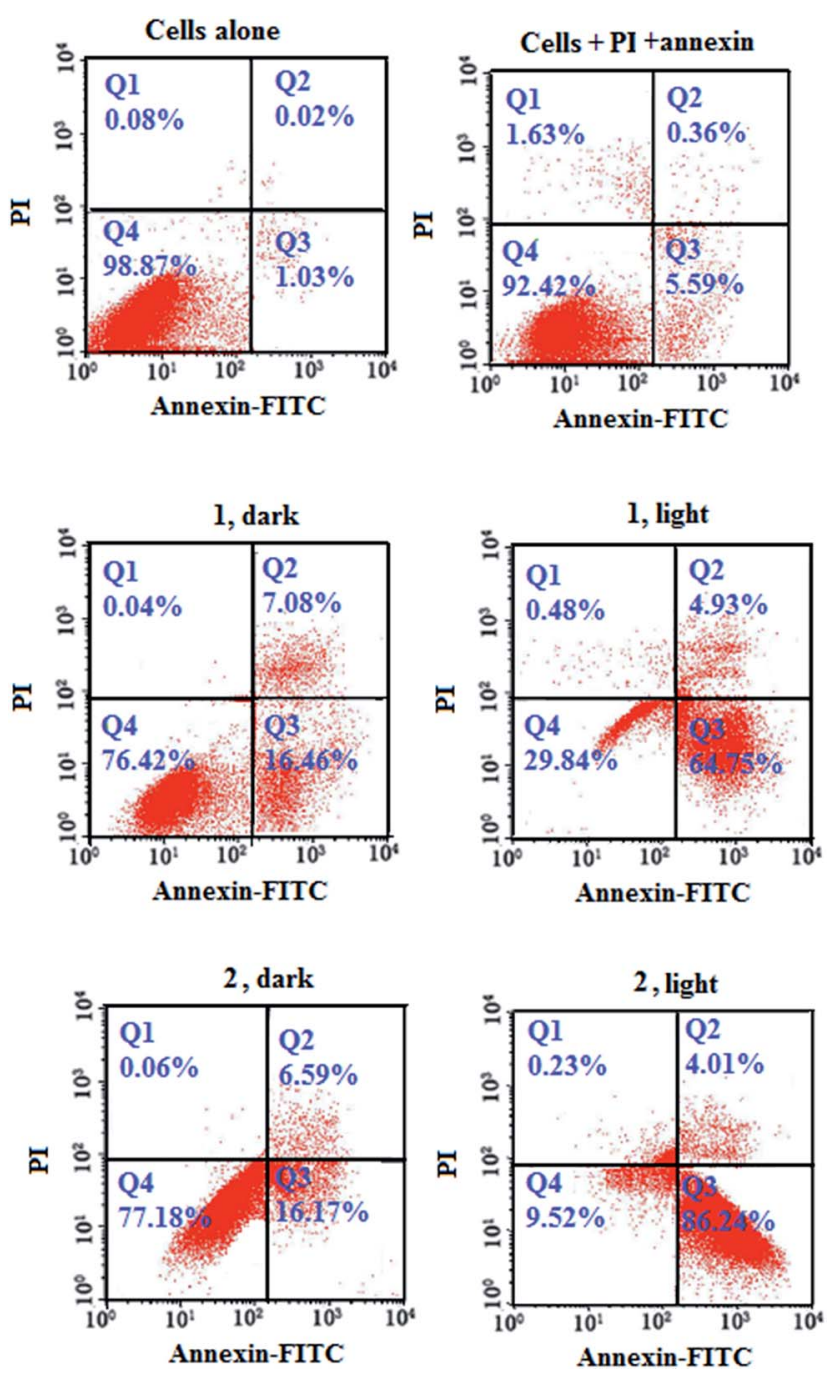

Fig. 8 Dot plots of annexinV-FITC/PI assay on HeLa cells treated with complexes 1 and 2 either kept in dark or exposed to photoreactor (500 $\mathrm{nm})$ as labeled showing \% cell populations in respective quadrants: FITC ${ }^{-} / \mathrm{PI}^{-}$lower left (Q3), viable cells; $\mathrm{FITC}^{+} / \mathrm{PI}^{-}$lower right (Q4), early apoptotic cells; FITC ${ }^{+} / \mathrm{PI}^{+}$upper right (Q2), late apoptotic cells; FITC ${ }^{-}$/ $\mathrm{PI}^{+}$upper left (Q1), necrotic cells. Representative data from three independent experiments are shown (pre-incubation: $4 \mathrm{~h}$ in dark, light exposure: $500 \mathrm{~nm}, 1 \mathrm{~h}$ ). 


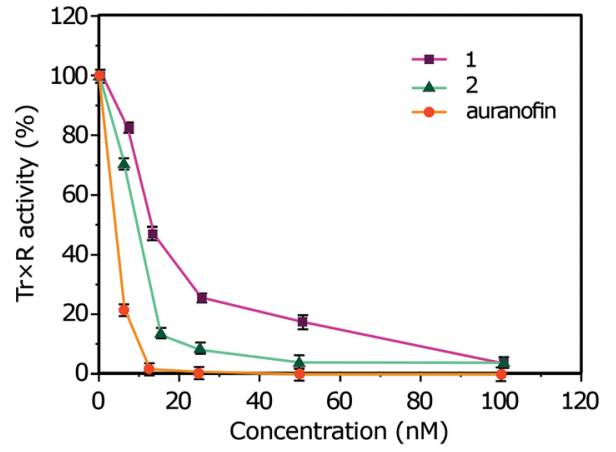

Fig. 9 Inhibitory effects of complexes 1 and 2 on TrxR. Error bars indicate the standard deviation.

complexes $\mathbf{1}$ and $\mathbf{2}$ were more effective than the positive control auranofin.

\section{Conclusions}

Two new cyclometalated $\operatorname{Ir}(\mathrm{III})$ complexes bearing NCN pincer, meso-phenylcyanamide BODIPY, and 2-phenylpyridine (1) or 1phenylisoquinoline (2) ligands have been demonstrated as photodynamic therapy agents (PDT). The DNA-binding interactions of the complexes with CT DNA display that the binding mode is mainly non-covalent via intercalation. The complexes $\mathbf{1}$ and 2 show cleavage SC-DNA efficiently on photoactivation at $500 \mathrm{~nm}$ with the formation of singlet oxygen $\left({ }^{1} \mathrm{O}_{2}\right)$ as reactive species to contribute in the cleavage process. The complexes 1 and 2 are significantly less toxic in the dark with $\mathrm{IC}_{50}$ values of $\sim 60 \mu \mathrm{M}$, while, upon light irradiation $(500 \mathrm{~nm}), 1$ and 2 were significantly photocytotoxic in HeLa cells with $\mathrm{IC}_{50}$ values of $0.78 \pm 0.1 \mu \mathrm{M}$ and $0.53 \pm 0.1 \mu \mathrm{M}$, respectively. These complexes showed very good uptake and efficient ROS generation in HeLa cell lines upon photoexposure to light of $500 \mathrm{~nm}$. Moreover, the complexes 1 and 2 revealed exceptional TrxR-inhibitory activities in comparison with auranofin. Therefore, the selenoenzyme TrxR may be as a protein target for cyclometalated $\operatorname{Ir}(\mathrm{III})$ complexes 1 and 2. Overall, these designing of cyclometalated iridium complexes can open new opportunities for metal-based PDT agents that may be used for a wide variety of applications as potential anticancer drugs.

\section{Experimental}

\subsection{General procedures, materials and physical} measurements

All manipulations were carried out under nitrogen atmosphere using standard Schlenk techniques and vacuum-line systems. Work-up procedures were performed in air. All materials used were received from commercial sources unless stated otherwise. The pincer ligand HL was synthesized as previously reported by us. ${ }^{41} 8$-(4-Anilino) BODIPY (boron dipyrromethene difluoro) was prepared according to literature method. ${ }^{60}$ All solvents were dried by standard procedures and freshly distilled prior to use. Human cervical cancer (HeLa), human fibroblast (MRC-5) nontumorigenic cells, and human plasma were supplied by the National Cell Bank of Pasteur Institute, Tehran, Iran. All reagents and cell culture media were purchased from Gibco Company (Germany). CT DNA was obtained from SigmaAldrich.

Fourier transform infrared spectra were recorded on a PerkinElmer Spectrum 400 (FT-IR/FT-NIR spectrometer). ${ }^{1} \mathrm{H},{ }^{13} \mathrm{C}\left\{{ }^{1} \mathrm{H}\right\}$ nuclear magnetic resonance (NMR) spectra were recorded on a Bruker-400 MHz spectrometer at ambient temperature in DMSO$d_{6}$. Elemental analyses were performed with an EA 3000 CHNS. Electronic absorption spectra were recorded on a JASCO $7580 \mathrm{UV}$ vis-NIR double-beam spectrophotometer. Emission intensity measurements were carried out using a Hitachi F 4500 spectrofluorometer. Luminescence quantum yields were measured in degassed acetonitrile using $\left[\mathrm{Ru}(\mathrm{bpy})_{3}\right] \mathrm{Cl}_{2}$ as the reference.

\subsection{Synthesis of ligands and the complexes 1 and 2}

4.2.1. Synthesis of 8-(4-phenylcyanamide) BODIPY, (PcydBODIPY). The ligand Pcyd-BODIPY was synthesized from 8-(4anilino) BODIPY as previously reported. ${ }^{40}$ Recrystallization from ethyl acetate/hexane $(1: 1)$ produced analytically pure orange solid (304 mg, 83.4\%, and $1 \mathrm{mmol}$ ). Anal. calc. (\%) for $\mathrm{C}_{20} \mathrm{H}_{19} \mathrm{BF}_{2} \mathrm{~N}_{4}$ (364.19): $\mathrm{C}, 65.96 ; \mathrm{H}, 5.26 ; \mathrm{N}, 15.38$; found (\%): $\mathrm{C}$, 65.92; H, 5.22; N, 15.33. IR (KBr): 2225 (vs., NCN), 1548, 1512 (m, $\mathrm{C}=\mathrm{C}, \mathrm{C}=\mathrm{N}), 1192(\mathrm{~m}, \mathrm{~B}-\mathrm{F}) \mathrm{cm}^{-1}$. TOF-MS: $365[\mathrm{M}+\mathrm{H}]^{+} .{ }^{1} \mathrm{H}$ NMR (DMSO- $d_{6}$ ): $\delta 8.132(\mathrm{~s}, 1 \mathrm{H}, \mathrm{H}-\mathrm{NH}), 6.95$ (d, 2H, H-11a or 12a, ${ }^{3} J$ 7.6), 6.77 (d, 2H, H-11a or 12a, ${ }^{3} J$ 7.6), 6.09 (s, $2 \mathrm{H}, \mathrm{H}-2 \mathrm{a}$ and H-6a), 2.28 (s, 6H, H-9a), 1.60 (s, 6H, H-10a). ${ }^{13} \mathrm{C}$ NMR (DMSO- $d_{6}$ ): $\delta 150.0$ (Ar), 140.1 (Ar), 138.0 (Ar), 136.0 (Ar), 133.1 (Ar), 131.6 (Ar), $129.9(\mathrm{Ar}), 127.1$ (Ar), $116.8(\mathrm{Ar}), 112.0(\mathrm{NCN})$, $12.5\left(\mathrm{C}-\mathrm{CH}_{3}\right), 10.2\left(\mathrm{C}-\mathrm{CH}_{3}\right)$.

4.2.2. Synthesis of $[\operatorname{Ir}(\mathrm{L})(\mathrm{PPY})(\mathrm{Pcyd}-\mathrm{BODIPY})], \quad 1 . \mathrm{IrCl}_{3^{-}}$ $\cdot x \mathrm{H}_{2} \mathrm{O}(0.29 \mathrm{~g}, 1 \mathrm{mmol})$ and pincer ligand $\mathrm{HL}(390 \mathrm{mg}, 1 \mathrm{mmol})$ in $\mathrm{MeOH} / \mathrm{CH}_{2} \mathrm{Cl}_{2}(20 \mathrm{~mL}, 1: 1, \mathrm{v} / \mathrm{v})$ was refluxed under an inert atmosphere of nitrogen for $12 \mathrm{~h}$. To this solution, PPY (2-phenylpyridine) (155 mg, $1 \mathrm{mmol}$ ) and Pcyd-BODIPY (8-(4-phenylcyanamide) BODIPY) (364 mg, $1 \mathrm{mmol}$ ) in $\mathrm{MeOH} / \mathrm{CH}_{2} \mathrm{Cl}_{2}$ $(30 \mathrm{~mL}, 1: 2, \mathrm{v} / \mathrm{v})$ was added. The $\mathrm{pH}$ of the solution was adjusted to $\sim 7$ using triethylamine. The solution was refluxed again under an inert atmosphere for $24 \mathrm{~h}$. The reaction mixture was then cooled to room temperature and then evaporated under vacuum. The residual orange solid was dissolved in $\mathrm{CH}_{2} \mathrm{Cl}_{2}$ and purified by column chromatography on silica gel. The desired product was eluted with $\mathrm{CH}_{2} \mathrm{Cl}_{2} / \mathrm{MeOH}(10: 1, \mathrm{v} / \mathrm{v})$ and subsequent recrystallized from $\mathrm{CH}_{2} \mathrm{Cl}_{2}$ /diethyl ether to afford an orange solid ( $954 \mathrm{mg}, 88.6 \%$ yield, and $1 \mathrm{mmol}$ ). Anal. calc. (\%) for $\mathrm{C}_{54} \mathrm{H}_{45} \mathrm{BF}_{2} \mathrm{IrN}_{9} \mathrm{O}$ (1077.02): C, 60.22; H, 4.21; N, 11.70; found (\%): C, 60.18; H, 4.18; N, 11.65. IR (KBr): 2092 (vs., $\mathrm{NCN})$, 1542, $1507(\mathrm{~m}, \mathrm{C}=\mathrm{C}, \mathrm{C}=\mathrm{N}), 1187(\mathrm{~m}, \mathrm{~B}-\mathrm{F}) \mathrm{cm}^{-1}$. TOFMS: $1078[\mathrm{M}+\mathrm{H}]^{+} .{ }^{1} \mathrm{H}$ NMR (DMSO- $\left.d_{6}\right): \delta 8.31\left(\mathrm{~d}, 2 \mathrm{H}, \mathrm{H}-4^{\prime},{ }^{3} J\right.$ 8.0), 8.24 (d, $1 \mathrm{H}, \mathrm{H}-5 \mathrm{~b},{ }^{3} J$ 7.6), $7.96\left(\mathrm{t}, 1 \mathrm{H}, \mathrm{H}-4 \mathrm{~b},{ }^{3} J 7.6\right), 7.86$ (d, 1H, H-12b, ${ }^{3} J$ 7.6), 7.68 (d, 1H, H-2b, ${ }^{3} J$ 7.6), 7.25 (t, 2H, H-6 ${ }^{\prime},{ }^{3} J$ 7.6), 6.94-7.01 (m, 9H, H-phenyl), 6.75 (s, 2H, H-3,5), 6.61 (d, $2 \mathrm{H}, \mathrm{H}-11 \mathrm{a}$ or $12 \mathrm{a},{ }^{3} J$ 7.6), 6.35 (d, 1H, H-9b, $\left.{ }^{3} J 7.6\right), 6.00$ (s, $2 \mathrm{H}, \mathrm{H}-$ 2a,6a), 3.80 (s, 3H, H-7), 3.49 (s, 6H, H-10'), 2.09 (s, 6H, H-9a), $1.60(\mathrm{~s}, 6 \mathrm{H}, \mathrm{H}-10 \mathrm{a}) .{ }^{13} \mathrm{C}$ NMR (DMSO- $\left.d_{6}\right): \delta 162.9$ (Ar), 159.9 
(Ar), 153.1 (Ar), 149.9 (Ar), 147.9 (Ar), 144.1 (Ar), 141.0 (Ar), 138.5 (Ar), 136.6 (Ar), 134.5 (Ar), 131.1 (Ar), 129.9 (Ar), 127.5 (Ar), 125.8 (Ar), 123.0 (Ar), 121.1 (Ar), 119.2 (Ar), 117.9 (Ar), 114.9 (Ar), 110.0 (NCN), $51.4(\mathrm{C}-7), 29.9\left(\mathrm{C}-10^{\prime}\right), 11.0\left(\mathrm{C}-\mathrm{CH}_{3}\right), 9.0\left(\mathrm{C}-\mathrm{CH}_{3}\right)$.

4.2.3. Synthesis of $[\operatorname{Ir}(\mathrm{L})(\mathrm{PIQ})($ Pcyd-BODIPY) $], 2$. The synthesis was carried out as described for 1, with PIQ (1-phenylisoquinoline) (205 mg, $1 \mathrm{mmol}$ ) instead of PPY. The residual orange solid was dissolved in $\mathrm{CH}_{2} \mathrm{Cl}_{2}$ and purified by column chromatography on silica gel. The desired product was eluted with $\mathrm{CH}_{2} \mathrm{Cl}_{2} / \mathrm{MeOH}(10: 1, \mathrm{v} / \mathrm{v})$ and subsequent recrystallized from $\mathrm{CH}_{2} \mathrm{Cl}_{2} /$ diethyl ether to afford an orange solid $(927 \mathrm{mg}$, 82.3\% yield, and $1 \mathrm{mmol}$ ). Anal. calc. (\%) for $\mathrm{C}_{58} \mathrm{H}_{47} \mathrm{BF}_{2} \mathrm{IrN}_{9} \mathrm{O}$ (1127.08): C, 61.81; H, 4.20; N, 11.18; found (\%): C, 61.76; H, 4.16; N, 11.12. IR (KBr): 2088 (vs., NCN), 1538, 1503 (m, C=C, $\mathrm{C}=\mathrm{N}), 1185(\mathrm{~m}, \mathrm{~B}-\mathrm{F}) \mathrm{cm}^{-1}$. TOF-MS: $1128[\mathrm{M}+\mathrm{H}]^{+} .{ }^{1} \mathrm{H}$ NMR (DMSO- $d_{6}$ ): $\delta 9.04$ (d, $1 \mathrm{H}, \mathrm{H}-8 \mathrm{~b},{ }^{3} J$ 7.6), 8.80 (d, $2 \mathrm{H}, \mathrm{H}-4^{\prime},{ }^{3} J 8.0$ ), 8.39 (d, 1H, H-16b, ${ }^{3} J$ 7.6), 8.05 (d, $1 \mathrm{H}, \mathrm{H}-5 \mathrm{~b},{ }^{3} J$ 7.6), 7.92 (t, $1 \mathrm{H}$, H-7b, ${ }^{3} J$ 7.6), 7.80 (t, 1H, H-6b, ${ }^{3} J$ 7.6), 7.60 (d, 2H, H-3b, 4b, ${ }^{3} J$ 7.6), 7.29 (t, 1H, H-15, ${ }^{3} J$ 7.6), 6.99-7.06 (m, 10H, H-phenyl), 6.79 (s, 2H, H-3,5), 6.61 (d, 2H, H-11a or $12 \mathrm{a},{ }^{3} J$ 7.6), $6.00(\mathrm{~s}, 2 \mathrm{H}, \mathrm{H}-$ 2a,6a), 3.70 (s, 3H, H-7), 3.40 (s, 6H, H-10'), 2.18 (s, 6H, H-9a), 1.49 (s, 6H, H-10a). ${ }^{13} \mathrm{C}$ NMR (DMSO- $d_{6}$ ): $\delta 166.1$ (Ar), 162.3 (Ar), 159.9 (Ar), 156.9 (Ar), 154.0 (Ar), 151.2 (Ar), 150.0 (Ar), 148.0 (Ar), 144.9 (Ar), 142.0 (Ar), 139.1 (Ar), 137.1 (Ar), 135.0 (Ar), 132.6 (Ar), 130.9 (Ar), 128.0 (Ar), 125.9 (Ar), 122.6 (Ar), 121.1 (Ar), 118.5 (Ar), $117.1(\mathrm{Ar}), 113.0(\mathrm{Ar}), 109.9(\mathrm{NCN}), 52.5(\mathrm{C}-7), 28.5\left(\mathrm{C}-10^{\prime}\right)$, $12.1\left(\mathrm{C}-\mathrm{CH}_{3}\right), 8.0\left(\mathrm{C}-\mathrm{CH}_{3}\right)$.

\subsection{Singlet oxygen quantum yields}

The singlet oxygen quantum yields were measured by two different methods, direct and indirect evaluation, as previously reported. ${ }^{37}$

\subsection{DNA binding studies}

The complexes were dissolved in $10 \mathrm{mM}$ Tris-HCl buffer $(\mathrm{pH}$ 7.4). The concentration of CT DNA was determined from the UV absorption intensity at $260 \mathrm{~nm}$ with $\varepsilon=6600 \mathrm{M}^{-1} \mathrm{~cm}^{-1} \cdot{ }^{61}$ The CT DNA solution in Tris-HCl buffer gave an absorbance ratio at 260 and $280 \mathrm{~nm}\left(A_{260} / A_{280}\right)$ of about 1.8-1.9 indicating that the CT DNA was sufficiently free of protein. The DNA concentration was varied between 0 and $100 \mu \mathrm{M}$, while the complex concentration was kept constant at $5.0 \mu \mathrm{M}$ at room temperature.

The intrinsic equilibrium binding constant $\left(K_{\mathrm{b}}\right)$ and the binding site size $(s)$ values were obtained from a nonlinear fitting according to the equation: ${ }^{62}$

$$
\begin{gathered}
\left(\varepsilon_{\mathrm{a}}-\varepsilon_{\mathrm{f}}\right) /\left(\varepsilon_{\mathrm{b}}-\varepsilon_{\mathrm{f}}\right)=\left[b-\left(b^{2}-2 K_{\mathrm{b}}{ }^{2} C_{\mathrm{t}}[\mathrm{DNA}] / s\right)^{1 / 2}\right] / 2 K_{\mathrm{b}} C_{\mathrm{t}} \\
b=1+K_{\mathrm{b}} C_{\mathrm{t}}+K_{\mathrm{b}}[\mathrm{DNA}] / 2 s
\end{gathered}
$$

where $\varepsilon_{\mathrm{a}}$ is the extinction coefficient observed for the charge transfer absorption band at a given DNA concentration, $\varepsilon_{\mathrm{f}}$ is the extinction coefficient of the complex free in solution, $\varepsilon_{\mathrm{b}}$ is the extinction coefficient of the complex when is fully bound to DNA, $C_{\mathrm{t}}$ is the total complex concentration, and [DNA] is the DNA concentration in nucleotides.
The observed linearity in the plot of $I_{0} / I v s$. the concentration ratio of the complexes to DNA is in good agreement with the linear Stern-Volmer equation: ${ }^{63}$

$$
I_{0} / I=1+K_{\mathrm{sv}}[\mathrm{Q}]
$$

where, $I_{0}$ and $I$ are the fluorescence intensities exhibited in the absence and presence of the compounds, respectively; [Q] corresponds to the concentration ratio of the compound to DNA. The slope of the plot of $I_{0} / I$ versus [Q] gives $K_{\mathrm{sv}}$.

The apparent binding constant $\left(K_{\text {app }}\right)$ of the complexes could be calculated using the following equation:

$$
K_{\text {app }}=K_{\mathrm{EB}}[\mathrm{EB}]_{50 \%} /[\text { complex }]_{50 \%}
$$

where $K_{\mathrm{EB}}$ is the DNA-binding constant of $\mathrm{EB}\left(K_{\mathrm{EB}}=1.0 \times\right.$ $10^{7} \mathrm{M}^{-1}$ ), and $[\mathrm{EB}]_{50 \%}$ and $[\text { complex }]_{50 \%}$ are the EB and complex concentrations that reduce the fluorescence by $50 \%$.

The photocleavage of SC pUC19 DNA $(0.2 \mu \mathrm{g}, 30 \mu \mathrm{M})$ by the complexes 1 and $2(30 \mu \mathrm{M}, 0.2 \mu \mathrm{g})$ in presence of complexes (100 $\mu \mathrm{M}$ ) was performed in Tris- $\mathrm{HCl} / \mathrm{NaCl}$ buffer $(50 \mathrm{mM}, \mathrm{pH} 7.2)$ by photo-irradiation of the samples with light of $500 \mathrm{~nm}\left(10 \mathrm{~J} \mathrm{~cm}^{-2}\right)$ by agarose gel electrophoresis. Mechanistic studies were performed using different additives as ROS scavengers/quenchers (TEMP, $0.2 \mathrm{mM}$; DABCO, $0.2 \mathrm{mM}$; $\mathrm{NaN}_{3}, 0.2 \mathrm{mM}$; KI, $0.2 \mathrm{mM}$; DMSO, $2 \mu \mathrm{L}$; catalase, 4 units; SOD, 4 units) prior to the addition of the complexes. After incubation of the sample for $1 \mathrm{~h}$ in dark and quenched by gel loading dye, solution was loaded on $1 \%$ agarose gel having $1 \mu \mathrm{g} \mathrm{mL} \mathrm{m}^{-1}$ ethidium bromide. Electrophoresis was run for $2.0 \mathrm{~h}$ at $60 \mathrm{~V}$ in Tris-acetate EDTA (TAE) buffer in dark room. The quantification of cleavage products was performed using UVITEC Fire Reader V4 gel documentation system and UVI band software. The error observed in measuring the band intensities was in the range of $4-7 \%$.

\subsection{Stability studies}

The stability of the complexes in plasma was assessed using a procedure analogous to that recently reported. ${ }^{37}$ An aliquot (25 $\mathrm{mL}$ ) of a solution containing the respective complexes $\mathbf{1}$ and 2 (final concentration $20 \mu \mathrm{M}$ ) and diazepam (final concentration $10 \mu \mathrm{M})$ in DMSO was added to human plasma solution $(975 \mathrm{~mL})$ to give a total volume of $1000 \mathrm{~mL}$. The resulting mixture was incubated for $72 \mathrm{~h}$ at $37^{\circ} \mathrm{C}$ with continuous and gentle shaking (ca. $300 \mathrm{rpm})$. The reaction was stopped by adding acetonitrile $(2 \mathrm{~mL})$, and the mixture was centrifuged for $45 \mathrm{~min}$ at $1000 \mathrm{~g}$ at $4{ }^{\circ} \mathrm{C}$. The acetonitrile was evaporated, and the residue was suspended in acetonitrile $/ \mathrm{H}_{2} \mathrm{O}(1: 1, \mathrm{v} / \mathrm{v} ; 200 \mathrm{~mL})$. The suspension was filtered and the filtrate was analyzed by HPLCUV. A $0.1 \mathrm{~mL}$ aliquot of the solution was injected into an HPLC system (Thermo, USA) connected to a UV/Vis spectrophotometer. A Hypersil Gold Dim $(100 \times 2.1 \mathrm{~mm}$, Thermo, USA $)$ reversed-phase column was used at a flow rate of $0.5 \mathrm{~mL} \mathrm{~min}^{-1}$. The runs were performed with a linear gradient of A (acetonitrile (Sigma-Aldrich HPLC-grade)) and B (distilled water containing $0.1 \% \mathrm{HCOOH}$ ): $t=0-3 \mathrm{~min}, 20 \% \mathrm{~A} ; t=7 \mathrm{~min}, 50 \% \mathrm{~A}$; $t=20 \mathrm{~min}, 90 \% \mathrm{~A} ; t=23 \mathrm{~min}, 100 \% \mathrm{~A} ; t=25 \mathrm{~min}, 100 \% \mathrm{~A} ; t=$ $28 \mathrm{~min}, 20 \% \mathrm{~A}$. 
Recoveries of diazepam and complexes $\mathbf{1}$ and $\mathbf{2}$ were determined by comparing the peak area ratios of the spiked drug-free plasma to the peak area ratios obtained by direct injection of the solutions of the same concentration of complexes 1 and 2 or diazepam (20 $\mu \mathrm{M}$ for complexes 1 and 2 and $10 \mu \mathrm{M}$ for diazepam).

\subsection{Cell culture}

Human cervical cancer (HeLa) and human fibroblast (MRC-5) nontumorigenic cells were maintained in Dulbecco's Modified Eagle Medium (DMEM) supplemented with 10\% FBS, 100 IU $\mathrm{mL}^{-1}$ of penicillin, $100 \mu \mathrm{g} \mathrm{mL} \mathrm{m}^{-1}$ of streptomycin and $2 \mathrm{mM}$ Glutamax at $37{ }^{\circ} \mathrm{C}$ in a humidified incubator at $5 \% \mathrm{CO}_{2}$. The adherent cultures were grown as monolayer and were passaged once in $4-5$ days by trypsinizing with $0.25 \%$ trypsin-EDTA.

\subsection{Cytotoxicity}

The photocytotoxicity of the complexes was studied using a standard MTT assay. ${ }^{64}$ Approximately 8000 HeLa cancer cells and MRC-5 nontumorigenic cells were plated separately in two different 96 wells culture plates in DMEM containing $10 \%$ FBS. Stock solutions of the complexes were prepared by dissolving the complexes in aqueous solutions with DMSO as the cosolvent and diluting with cell culture medium to the desired concentrations. The final DMSO concentration never exceeded $1 \% \mathrm{v} / \mathrm{v}$. Cells were then treated with increasing concentrations of compounds for $24 \mathrm{~h}$. Dark controls, or cytotoxicity (CT) assays, refer to assays that include metal complex but were not exposed to light, and light controls refer to light exposed assays that did not contain metal complex. Photocytotoxicity (PCT) assays contained metal complex and were exposed to light. For phototoxicity studies, cells were treated for $4 \mathrm{~h}$ only with increasing concentrations of the compounds. After that, the medium was removed and replaced by fresh complete medium prior to $20 \mathrm{~min}$ irradiation at $50 \mathrm{~nm}\left(10 \mathrm{~J} \mathrm{~cm}^{-2}\right)$. After $44 \mathrm{~h}$ in the incubator, the medium was replaced by $100 \mathrm{~mL}$ complete medium containing resazurin $\left(0.2 \mathrm{mg} \mathrm{mL}^{-1}\right.$ final concentration). After $4 \mathrm{~h}$ incubation at $37^{\circ} \mathrm{C}$, fluorescence of the highly red fluorescent resorufin product was quantified at $590 \mathrm{~nm}$ emission with $540 \mathrm{~nm}$ excitation wavelength in a SpectraMax M5 microplate reader. Light doses were evaluated with a Gigahertz Optic X1-1 optometer. Cell counts were carried out immediately after light exposure. All experiments were carried out in triplicate, and the graphed data is the average of three trials.

The LED light sources were monitored using an International Light Technologies Powermeter (ILT2400) equipped with SED 623 detector and spectral range 200-2100 nm. Light doses were evaluated with a Gigahertz Optic X1-1 optometer. The light doses employed in this work are comparable to those employed for activation of other metal-based phototoxic compounds (2$11.5 \mathrm{~J} \mathrm{~cm}^{-2}$ at $\left.400-600 \mathrm{~nm}\right) .{ }^{65-69}$

\subsection{ICP-MS}

Cells grown in a $60 \mathrm{~mm}$ tissue culture dish were incubated with the iridium(III) complexes $(100 \mu \mathrm{M})$ in glucose-free medium at
$37{ }^{\circ} \mathrm{C}$ under a $5 \% \mathrm{CO}_{2}$ atmosphere for $5 \mathrm{~min}$. The medium was removed, and the cell layer was washed gently with $10 \mathrm{~mL}$ PBS. Then, the cells were digested with $65 \% \mathrm{HNO}_{3}(2 \mathrm{~mL})$ at $50{ }^{\circ} \mathrm{C}$ for $2 \mathrm{~h}$ and trypsinized and harvested with $20 \mathrm{~mL}$ PBS. The solution was analyzed using NexION 2000 B ICP Mass.

\subsection{DCFDA assays}

DCFDA assay was done to quantify ROS on the oxidative production of fluorescent DCF $\left(\lambda_{\mathrm{em}}=525 \mathrm{~nm}\right)$. HeLa cells $(2 \times$ $10^{5}$ cells plated in duplicate) were incubated in the presence or absence of complexes $\mathbf{1}$ and $\mathbf{2}$ (concentration $=\mathrm{IC}_{50}$ values in light) for $4 \mathrm{~h}$ in the dark with or without photoirradiation in DPBS (500 nm, $1 \mathrm{~h}$ ). Cells were trypsinized and treated with 1 $\mu \mathrm{M}$ DCFDA for $15 \mathrm{~min}$, and the stained cells were determined by flow cytometry.

\subsection{Annexin V-FITC/PI assay}

HeLa cells $\left(2 \times 10^{5}\right)$ were incubated (concentration $=\mathrm{IC}_{50}$ values in light) for $24 \mathrm{~h}$ followed by light treatment in DPBS (500 $\mathrm{nm})$. Cells were further kept for $12 \mathrm{~h}$ post-treatment and then trypsinized. Annexin VFITC $(2 \mu \mathrm{L})$ and propidium iodide (PI; 1 $\mu \mathrm{L}$ ) were then added to clear suspensions of cells in $500 \mu \mathrm{L}$ of a $1 \times$ binding buffer and kept in the dark for $10 \mathrm{~min}$. The percent cell population in each quadrant was estimated by FACS analysis. Experiments were performed in triplicate along with untreated controls for reference.

\subsection{TrxR inhibition}

Thioredoxin reductases (Trx-R) sourced from rat liver was obtained from Sigma-Aldrich. It is a buffered aqueous glycerol solution, $\geq 100$ units per $\mathrm{mg}$ protein, in $50 \mathrm{mM}$ Tris- $\mathrm{HCl}, \mathrm{pH}$ 7.5, $300 \mathrm{mM} \mathrm{NaCl}, 1 \mathrm{mM}$ EDTA, and 10\% glycerol. The complexes 1, 2, and auranofin were preincubated for $5 \mathrm{~min}$ at room temperature; the reaction started with $2 \mathrm{mM} 5,5^{\prime}$ dithiobis(2-nitrobenzoic acid) (DTNB), and the increase of the absorbance was monitored at $412 \mathrm{~nm}$ over $5 \mathrm{~min}$ at $25^{\circ} \mathrm{C}$. The reaction velocity in the presence of inhibitor was normalized relative to the control to generate percent activity and plots of percent activity versus concentration were constructed to obtain $\mathrm{IC}_{50}$ values (that is, the concentration that inhibited $50 \%$ of enzyme activity).

\section{Acknowledgements}

We are grateful for general support from the Department of Chemistry, Isfahan University of Technology (IUT).

\section{References}

1 R. Bonnett, Chemical aspects of photodynamic therapy, CRC Press, 2000.

2 D. E. Dolmans, D. Fukumura and R. K. Jain, Nat. Rev. Cancer, 2003, 3, 380-387.

3 M. R. Hamblin and T. Hasan, Photochem. Photobiol. Sci., 2004, 3, 436-450.

4 P. R. Ogilby, Chem. Soc. Rev., 2010, 39, 3181-3209. 
5 P. Agostinis, K. Berg, K. A. Cengel, T. H. Foster, A. W. Girotti, S. O. Gollnick, S. M. Hahn, M. R. Hamblin, A. Juzeniene, D. Kessel, M. Korbelik, J. Moan, P. Mroz, D. Nowis, J. Piette, B. C. Wilson and J. Golab, Ca-Cancer J. Clin., 2011, 61, 250-281.

6 http:/www.theralase.com/pressrelease/health-canada-approvesclinical-trialapplication-anti-cancer-drug/.

7 P. Kaspler, S. Lazic, S. Forward, Y. Arenas, A. Mandel and L. Lilge, Photochem. Photobiol. Sci., 2016, 15, 481.

8 J. Fong, K. Kasimova, Y. Arenas, P. Kaspler, S. Lazic, A. Mandel and L. Lilge, Photochem. Photobiol. Sci., 2015, 14, 2014.

9 T. Sainuddin, J. McCain, M. Pinto, H. Yin, J. Gibson, M. Hetu and S. A. McFarland, Inorg. Chem., 2016, 55, 83-95.

10 A. Leonidova, V. Pierroz, R. Rubbiani, J. Heier, S. Ferrari and G. Gasser, Dalton Trans., 2014, 43, 4287-4294.

11 A. Leonidova and G. Gasser, ACS Chem. Biol., 2014, 9, 21802193.

12 L. He, Y. Li, C.-P. Tan, R.-R. Ye, M.-H. Chen, J.-J. Cao, L.-N. Ji and Z.-W. Mao, Chem. Sci., 2015, 6, 5409-5418.

13 L. K. McKenzie, I. V. Sazanovich, E. Baggaley, M. Bonneau, V. Guerchais, J. A. Williams, J. A. Weinstein and H. E. Bryant, Chemistry, 2017, 23, 234-238.

14 S. Betanzos-Lara, L. Salassa, A. Habtemariam, O. Novakova, A. M. Pizarro, G. J. Clarkson, B. Liskova, V. Brabec and P. J. Sadler, Organometallics, 2012, 31, 3466-3479.

15 R. E. Doherty, I. V. Sazanovich, L. K. McKenzie, A. S. Stasheuski, R. Coyle, E. Baggaley, S. Bottomley, J. A. Weinstein and H. E. Bryant, Sci. Rep., 2016, 6, 22668, DOI: $10.1038 /$ srep22668.

16 A. Kando, Y. Hisamatsu, H. Ohwada, T. Itoh, S. Moromizato, M. Kohno and S. Aoki, Inorg. Chem., 2015, 54, 5342-5357.

17 R. Cao, J. L. Jia, X. C. Ma, M. Zhou and H. Fei, J. Med. Chem., 2013, 56, 3636-3644.

18 C. Yang, F. Mehmood, T. L. Lam, S. L. F. Chan, Y. Wu, C. S. Yeung, X. G. Guan, K. Li, C. Y. S. Chung, C. Y. Zhou, T. T. Zou and C. M. Che, Chem. Sci., 2016, 7, 3123-3136.

19 W. H. Wang, Z. F. Mao, M. D. Wang, L. J. Liu, D. W. J. Kwong, C. H. Leung and D. L. Ma, Chem. Commun., 2016, 52, 36113614.

20 D. Maggioni, M. Galli, L. DAlfonso, D. Inverso, M. V. Dozzi, L. Sironi, M. Iannacone, M. Collini, P. Ferruti, E. Ranucci and G. D'Alfonso, Inorg. Chem., 2015, 54, 544-553.

21 L. He, Y. Li, C. P. Tan, R. R. Ye, M. H. Chen, J. J. Cao, L. N. Ji and Z. W. Mao, Chem. Sci., 2015, 6, 5409-5418.

22 F. Xue, Y. Lu, Z. Zhou, M. Shi, Y. Yan, H. Yang and S. Yang, Organometallics, 2015, 34, 73-77.

23 C. Wang, L. Lystrom, H. Yin, M. Hetu, S. Kilina, S. A. McFarland and W. Sun, Dalton Trans., 2016, 45, 16366-16378.

24 J. S. Nam, M. G. Kang, J. Kang, S. Y. Park, S. J. C. Lee, H. T. Kim, J. K. Seo, O. H. Kwon, M. H. Lim, H. W. Rhee and T. H. Kwon, J. Am. Chem. Soc., 2016, 138, 10968-10977.

25 X. Jiang, J. Peng, J. Wang, X. Guo, D. Zhao and Y. Ma, ACS Appl. Mater. Interfaces, 2016, 8, 3591-3600.
26 L. K. McKenzie, I. V. Sazanovich, E. Baggaley, M. Bonneau, V. Guerchais, J. A. G. Williams, J. A. Weinstein and H. E. Bryant, Chem.-Eur. J., 2017, 23, 234-238.

27 W. Lv, Z. Zhang, K. Y. Zhang, H. Yang, S. Liu, A. Xu, S. Guo, Q. Zhao and W. Huang, Angew. Chem., Int. Ed., 2016, 55, 9947-9951; Angew. Chem., 2016, 128, 1010110105.

28 Q.-X. Zhou, W.-H. Lei, Y.-J. Hou, Y.-J. Chen, C. Li, B.-W. Zhang and X.-S. Wang, Dalton Trans., 2013, 42, 27862791.

29 T. Wang, Y. Hou, Y. Chen, K. Li, X. Cheng, Q. Zhou and X. Wang, Dalton Trans., 2015, 44, 12726-12734.

30 P. Majumdar, X. Yuan, S. Li, B. L. Guennic, J. Ma, C. Zhang, D. Jacqueminde and J. Zhao, J. Mater. Chem. B, 2014, 2, 28382854.

31 R. Lincoln, A. M. Durantini, L. E. Greene, S. R. Martínez, R. Knox, M. C. Becerra and G. Cosa, Photochem. Photobiol. Sci., 2017, 16, 178-184.

32 K. Krumova and G. Cosa, J. Am. Chem. Soc., 2010, 132, 1756017569.

33 M. Jazestani, H. Chiniforoshan, L. Tabrizi and P. McArdle, J. Biomol. Struct. Dyn., 2017, 35, 2055-2065.

34 L. Tabrizi and H. Chiniforoshan, Dalton Trans., 2017, 46, 2339-2349.

35 L. Tabrizi, P. McArdle, A. Erxleben and H. Chiniforoshan, Inorg. Chim. Acta, 2015, 438, 94-104.

36 L. Tabrizi and H. Chiniforoshan, Invest. New Drugs, 2016, 34, 723-732.

37 L. Tabrizi and H. Chiniforoshan, Dalton Trans., 2016, 45, 18333-18345.

38 M. Jazestani, H. Chiniforoshan, L. Tabrizi, P. McArdle and B. Notash, Inorg. Chim. Acta, 2016, 450, 402-410.

39 L. Tabrizi and H. Chiniforoshan, BioMetals, 2017, 30, 5970.

40 R. J. Crutchley, Coord. Chem. Rev., 2001, 219-221, 125-155.

41 L. Tabrizi and H. Chiniforoshan, RSC Adv., 2016, 6, 9334993355.

42 H. Huang, B. Yu, P. Zhang, J. Huang, Y. Chen, G. Gasser, L. Ji and H. Chao, Angew. Chem., Int. Ed., 2015, 54, 14049-14052.

43 (a) J. Karolin, L. B. A. Johansson, L. Strandberg and T. Ny, J. Am. Chem. Soc., 1994, 116, 7801-7806; (b) G. Meng, S. Velayudham, A. Smith, R. Luck and H. Liu, Macromolecules, 2009, 42, 1995-2001; (c) J. M. Zimbron, K. Passador, B. Gatin-Fraudet, C.-M. Bachelet, D. Plażuk, L.-M. Chamoreau, C. Botuha, S. Thorimbert and M. Salmain, Organometallics, 2017, DOI: 10.1021/ acs.organomet.7b00250; (d) T. Rohand, W. Qin, N. Boens and W. Dehaen, Eur. J. Org. Chem., 2006, 4658-4663; (e) X. Yin, Y. Li, Y. Zhu, X. Jing, Y. Li and D. Zhu, Dalton Trans., 2010, 39, 9929-9935.

44 S. P.-Y. Li, C. T.-S. Lau, M.-W. Louie, Y.-W. Lam, S. H. Cheng and K. K.-W. Lo, Biomaterials, 2013, 34, 7519-7532.

45 J. X. Zhang, J. W. Zhou, C. F. Chan, T. C. K. Lau, D. W. J. Kwong, H. L. Tam, N. K. Mak, K. L. Wong and W. K. Wong, Bioconjugate Chem., 2012, 23, 1623-1638. 
46 S. P. Foxon, M. A. H. Alamiry, M. G. Walker, A. J. H. M. Meijer, I. V. Sazanovich, J. A. Weinstein and J. A. Thomas, J. Phys. Chem. A, 2009, 113, 12754-12762.

47 J. Yang, Q. Cao, W.-L. Hu, R.-R. Ye, L. He, L.-N. Ji, P. Z. Qin and Z.-W. Mao, Dalton Trans., 2017, 46, 445-454.

48 C. Mari, V. Pierroz, R. Rubbiani, M. Patra, J. Hess, B. Spingler, L. Oehninger, J. Schur, I. Ott, L. Salassa, S. Ferrari and G. Gasser, Chem.-Eur. J., 2014, 20, 1442114436.

49 G. Zuber, J. C. Quada and S. M. Hecht Jr, J. Am. Chem. Soc., 1998, 120, 9368-9369.

50 S. M. Hecht, J. Nat. Prod., 2000, 63, 158-168.

51 S. Saha, R. Majumdar, M. Roy, R. R. Dighe and A. R. Chakravarty, Inorg. Chem., 2009, 48, 2652-2663.

52 F. J. Meyer-Almes and D. Porschke, Biochemistry, 1993, 32, 4246-4253.

53 R. F. Pasternack, M. Caccam, B. Keogh, T. A. Stephenson, A. P. Williams and A. E. J. Gibbst, J. Am. Chem. Soc., 1991, 113, 6835-6840.

54 B. Maity, M. Roy, B. Banik, R. Majumdar, R. R. Dighe and A. R. Chakravarty, Organometallics, 2010, 29, 3632-3641.

55 E. Delaey, F. van Laar, D. De Vos, A. Kamuhabwa, P. Jacobs and P. de Witte, J. Photochem. Photobiol., B, 2000, 55, 27-35.

56 P. Majumdar, X. Yuan, S. Li, B. L. Guennic, J. Ma, C. Zhang, D. Jacqueminde and J. Zhao, J. Mater. Chem. B, 2014, 2, 28382854.

57 K. K.-W. Lo, W. H.-T. Law, J. C.-Y. Chan, H.-W. Liu and K. Y. Zhang, Metallomics, 2013, 5, 808-812.
58 W. H.-T. Law, L. C.-C. Lee, M.-W. Louie, H.-W. Liu, T. W.-H. Ang and K. K.-W. Lo, Inorg. Chem., 2013, 52, 13029-13041.

59 C. Liu, Z. Liu, M. Li, X. Li, Y. S. Wong, S. M. Ngai, W. Zheng, Y. Zhang and T. Chen, PLoS One, 2013, 8, e53945.

60 A. Cui, X. Peng, J. Fan, X. Chen, Y. Wu and B. Guo, J. Photochem. Photobiol., A, 2007, 186, 85-92.

61 Y. Gultneh, A. R. Khan, D. Blaise, S. Chaudhry, B. Ahvani, B. B. Marvey and R. J. Butcher, J. Inorg. Biochem., 1999, 75, 7-18.

62 L. Tabrizi, M. Fooladivanda and H. Chiniforoshan, BioMetals, 2016, 29, 981-993.

63 J. R. Lakowicz and G. Weber, Biochemistry, 1973, 12, 41614170.

64 T. Mosmann, J. Immunol. Methods, 1983, 65, 55-63.

65 C. Mari, V. Pierroz, R. Rubbiani, M. Patra, J. Hess, B. Spingler, L. Oehninger, J. Schur, I. Ott, L. Salassa, S. Ferrari and G. Gasser, Chem.-Eur. J., 2014, 20, 14421.

66 J. X. Zhang, J. W. Zhou, C. F. Chan, T. C. K. Lau, D. W. J. Kwong, H. L. Tam, N. K. Mak, K. L. Wong and W. K. Wong, Bioconjugate Chem., 2012, 23, 1623.

67 N. J. Farrer, J. A. Woods, V. P. Munk, F. S. Mackay and P. J. Sadler, Chem. Res. Toxicol., 2010, 23, 413.

68 C. Mari, H. Huang, R. Rubbiani, M. Schulze, F. Würthner, H. Chao and G. Gasser, Eur. J. Inorg. Chem., 2017, 2017, 1745-1752.

69 A. K. Renfrew, N. S. Bryce and T. Hambley, Chem.-Eur. J., 2015, 21, 15224. 